\title{
A comparison of feeding reconstituted and dried milk upon the growth and carcass composition of calves
}

\author{
By W. J. PRYOR and J. H. TERNOUTH \\ Department of Animal Husbandry, Veterinary School, \\ University of Queensland, St Lucia, Queensland, ${ }_{4} 067$, Australia
}

(Received 14 fuly 1971-Accepted 9 November 1971)

\begin{abstract}
I. The live-weight gain, carcass weight, edible carcass composition, efficiency of food conversion, and roughage intake were measured in three groups of calves fed for $87 \mathrm{~d}$. After a 3 -week feeding period on a common regimen, one group of calves was weaned on to a diet of dry whole-milk powder and chopped lucerne, the second group received a similar diet except that the whole-milk powder was reconstituted to a liquid milk, containing $12-15 \%$ dry matter. The third group was given the diet in the same manner as the second group except that the chopped lucerne was available $a d l i b$.

2. The mean live-weight gains for the three groups were $37 \cdot 7,47 \cdot 6$ and $52 \cdot 7 \mathrm{~kg}$ respectively, the differences between the dry-fed and the liquid-fed groups being highly significant.

3. Energy and nitrogen accretion in the edible carcass and efficiency of food conversion were superior in the second and third groups.

4. The third group ate larger quantities of roughage, though the difference did not reach significance.

5. The reasons for the superiority of the liquid milk diet are discussed in relation to the avoidance of ruminal fermentation of the milk.
\end{abstract}

The site of digestion of certain components of the diets given to ruminant animals has been the subject of considerable attention in recent years. 'The advantages of minimizing ruminal digestion of high-quality proteins have been shown by Zelter $\&$ Leroy ( $1966-7$ ), Ferguson, Hemsley \& Reis (1967) and Reis \& Tunks (I969). A coating of formaldehyde-' protected' proteins has been used to prevent ruminal hydrogenation of dietary unsaturated fatty acids (Scott, Cook, Ferguson, McDonald, Buchanan \& Hills, 1970).

An alternative and very efficient method of avoiding ruminal degradation of highly fermentable foods, by giving them in liquid form so that the reticular groove reflex is activated, was recently re-emphasized by Ørskov \& Benzie (1969). In lambs, Ørskov, Fraser \& Corse (1970) have shown the nutritional advantages of giving proteins in liquid form. Similar differences in weight gains of calves given liquid rather than dry diets have been observed by Swanson, Thigpen, Huskey \& Hazlewood ( 1969$)$ and Ternouth \& Pryor (1970), both of whom gave part of the ration either as a concentrate containing dry milk, or as liquid milk, or both. In the experiments of Ternouth \& Pryor, two groups of calves had very similar intakes of energy and nitrogen but the live-weight gains were markedly superior when the calves received part of the diet as liquid milk. It was also noted that the improved live-weight gain was almost entirely in the form of increased carcass weight.

The present experiment was designed to examine the effect of feeding identical quantities of dried whole milk, either reconstituted or in dry form, to calves upon 
their growth rate, efficiency of food conversion and some characteristics of their carcasses and edible tissues at 12 weeks of age.

\section{EXPERIMENTAL}

\section{Animals and diets}

On 20 September I968, six Australian Illawarra Shorthorn male calves (designated group DM) were purchased by a professional calf buyer at a local market, and I week later a further twelve male calves were purchased. The calves purchased were chosen with the aim of securing uniformity of size, weight and an estimated age of $4 \mathrm{~d}$ at the time of purchase.

The general management of the calves was similar to that described by Ternouth $\&$ Pryor (I970), the calves being individually penned in concretc-floored pens; no bedding was provided. The liquid milk was given by teat, the normal times of feeding being 09.00 and 17.00 hours. Drinking-water was freely available to all the calves except for a period of $16 \mathrm{~h}$ immediately before the time when the calves were weighed. The calves were weighed weekly throughout the experiment, immediately before the morning feed.

Calves in group DM were each offered 20.31 raw milk during the ist week after purchase and $2 \mathrm{r} \cdot 61$ during the and week. During the and week the calves were offered, and actively encouraged to eat, chopped lucerne. This chopped lucerne was available $a d l i b$. throughout the remainder of the experiment. During the $3^{\text {rd week, the calves }}$ were progressively weaned and were offered only 13.41 raw milk until weaning at $25 \mathrm{~d}$ of age. They were offered and encouraged to eat a mixture of $90 \%$ dried-milk powder and $10 \%$ chopped lucerne ( $92 \%$ and $90 \%$ dry matter, respectively), which was also provided ad lib. The milk powder had been pasteurized at a temp of $110^{\circ}$ for $3-5 \mathrm{~s}$ before spray-drying. A sample of milk powder which had undergone similar pasteurization and drying treatment was found on chemical analysis (Aschaffenburg \& Drewry, I959) to contain $0.38 \mathrm{~g}$ non-casein $\mathrm{N}$ and $3.93 \mathrm{~g} \mathrm{~N} / \mathrm{r} 00 \mathrm{~g}$ air-dry powder and a reconstituted sample had poor in vitro clotting ability with rennet (Roy, I970a). The lucerne was included with the milk powder to improve the palatability and reduce the dustiness of the milk powder. The calves were offered dry-milk powder + lucerne and chopped lucerne, both ad lib., for a further $66 \mathrm{~d}$, the weight of food consumed being recorded daily.

The twelve calves purchased I week later were randomly allocated into two groups (LM and LMLA). Calves in both groups were offered the same quantities of raw milk as the calves in group DM had been offered during the first 3 weeks. From the commencement of the 3 rd week of the experiment, each calf in groups LM and LMIA was offered the same mean quantity of milk powder, reconstituted in water at $39^{\circ}$, as the group DM calves had ingested during the same day of the previous week. Water $\left(39^{\circ}\right)$ was added to the milk powder in $284 \mathrm{ml}(0.5$ pint) increments so that the reconstituted milk had a final dry-matter content of I2-I $5 \%$. Group LM calves were also offered the same mean quantities of chopped lucerne as the DM calves had eaten during the same day of the previous week. Group LMLA calves were offered chopped 
lucerne $a d$ lib. All the calves were killed $87 \mathrm{~d}$ after purchase, after being deprived of food and water for $16 \mathrm{~h}$.

During the Ist week after purchase, all calves were given suitable prophylactic treatments for bacterial and coccidial infections of the gastro-intestinal tract and external parasitic infections. The health of all calves remained good.

\section{Analysis of food}

Each bag of milk powder and chopped lucerne was sampled and the gross energy (GE) and N contents were measured as described by Ternouth \& Pryor (1970). The mean contents of the milk powder and chopped lucerne were $5.87 \mathrm{kcal}(24.56 \mathrm{~kJ})$ and $5.09 \mathrm{kcal}(2 \mathrm{I} \cdot 29 \mathrm{~kJ}) \mathrm{GE} / \mathrm{ro0} \mathrm{g}$ dry matter and 4.26 and $4.34 \mathrm{~g} \mathrm{~N} / \mathrm{I} 00 \mathrm{~g}$ dry matter respectively.

\section{Treatment of carcass}

The calves were killed by stunning and exsanguination, dressed, and the weights of carcasses were recorded. A carcass is defined as the weight of the calf after removal of the head, skin, contents of the thoracic, abdominal and pelvic cavities (including the diaphragm and kidneys) and the limbs distal to the carpal and tarsal joints. The carcasses were then hung in a cold room at $2^{\circ}$ for $\mathrm{I} 2 \mathrm{~h}$ before being divided along the midline. The right sides of the commercial carcass were then 'boned out', i.e. divided into $(a)$ bones and ligamentum nuchae, $(b)$ edible tissues, consisting of muscles, fat and connective tissue. The total edible tissue from the right side of each commercial carcass was minced and sampled, then freeze-dried and stored as described by Ternouth \& Pryor (1970), until subjected to chemical analyses. Edible carcass tissue was analysed for energy and $N$ content ('Ternouth \& Pryor, r970) and for fat content by the Soxhlet method (Association of Official Agricultural Chemists, 1965 ) by means of a light petroleum extraction for $16 \mathrm{~h}$.

\section{RESULT'S}

The mean intakes of food by the three groups of calves are shown in Table r. One calf in group DM refused some liquid milk during the Ist week after purchase (week I) and one calf in group LM did not consume some chopped lucerne during the 8th week of the experiment. Fig. I shows the quantities of milk and chopped lucerne consumed by the calves during each week of the experiment. The intake of dry milk and lucerne by the group DM calves increased throughout the experiment and the mean lucerne intake of the group LMLA calves was consistently higher than that of the DM calves (Fig. I) though the differences were not significant. Table 2 shows the gross energy and $\mathrm{N}$ intakes of the calves. There were no significant differences in the energy intakes and $\mathrm{N}$ intakes between groups DM and LM, although energy intakes and $\mathrm{N}$ intakes of calves in group LMLA were $14 \%$ and $25 \%$ higher, respectively.

Fig. I also shows the mean live weights of the three groups of calves throughout the experiment. Calves given liquid milk (LM, LMLA) grew at a faster rate throughout the experiment (Table 3), so that at the end of the experiment there was a difference in live weight of $11.4 \mathrm{~kg}$ between the two groups of calves although they had ingested 
Table I. Mean food intakes from 4 to 91 $d$ of age for groups of six calves fed on dried whole milk, offered either as a dry powder (DM) or reconstituted (LM and LMLA), and lucerne

$\begin{array}{lccc} & \text { DM } & \text { LM } & \text { LMLA } \\ \text { Raw milk (1) } & 55^{\circ} & 55 \cdot 4 & 55 \cdot 4 \\ \begin{array}{l}\text { Milk powder (kg*) } \\ \quad \text { As a dry powder }\end{array} & 36 \cdot 49 \pm 4 \cdot 33 \dagger & - & - \\ \quad \text { Reconstituted } & - & 36 \cdot 49 & 36 \cdot 49 \\ \text { Chopped lucerne (kg*) } & 73 \cdot 29 \pm 2 \cdot 84 \dagger & 74 \cdot 30 & 90 \cdot 52 \pm 8 \cdot 98 \dagger\end{array}$

* On an air-dry basis.

$\dagger$ Mean values with their standard errors; where no standard errors are given, all calves had similar intakes.

Table 2. Total energy and $N$ intakes from 25 to $9 \mathrm{I} d$ of age of three groups of six calves fed on dried whole milk, offered either as a dry powder $(D M)$ or reconstituted ( $L M$ and LMLA), and lucerne

(Mean values with their standard errors)

\begin{tabular}{|c|c|c|c|}
\hline & DM & LM & LMLA \\
\hline $\begin{array}{l}\text { Energy intake } \\
\text { (Mcal) } \\
\text { (MI) }\end{array}$ & $\begin{array}{r}523 \cdot 5 \pm 27 \cdot 3 \\
2191 \cdot 1+114 \cdot 3\end{array}$ & $\begin{array}{r}528 \cdot 3 \pm 0 \cdot 1 \\
2211 \cdot 2 \pm 0.4\end{array}$ & $\begin{array}{r}596 \cdot 1 \pm 41 \cdot 2 \\
2495^{\circ} 0 \pm 172 \cdot 4\end{array}$ \\
\hline$N$ intake $(g)$ & $4222 \cdot 0 \pm 208 \cdot 2$ & $4262 \cdot 9 \pm 1 \cdot 0$ & $5285.8 \pm 737.8$ \\
\hline
\end{tabular}

identical quantities of food (groups DM and LIM). Most of this difference in live weight was due to differences in carcass weight $(8.8 \mathrm{~kg})$, of which $7.5 \mathrm{~kg}$ was the contribution of edible tissues. The feeding of lucerne ad lib. (LMLA) resulted in some additional increase in live weight compared with that of the calves in group LM, but the LMLA calves had a lower dressing percentage so there was little difference in carcass weight between the LM and LMLA calves.

The calves given diet DM had poorer efficiencies of food conversion than the calves given their milk in liquid form. The efficiency of conversion of lucerne tended to be better when it was offered at restricted levels (LM) than when it was given ad lib. (LMLA).

The total amounts of energy and fat in the edible carcasses of the faster-growing calves fed on liquid milk (LM) were significantly higher than in the calves fed on dried milk, whereas the total $\mathrm{N}$ in the carcasses was less (Table 4). The total quantity of fat in the edible carcass was nearly twice as high when the calves were given liquid milk, and the total quantities of both energy and $\mathrm{N}$ were also considerably higher, these differences reflecting the large differences in edible carcass-weight dry matter.

\section{DISCUSSION}

As in the earlier experiments of Ternouth \& Pryor (1970), the nutritional advantages of feeding milk in a liquid form have been shown. Live-weight gain was $26 \%$ greater in the calves fed on liquid milk (group LM) than in those fed on the dried-milk powder (group DM), during the period $25^{-9} \mathrm{I}$ d of age. Similarly, calves in group LMLA 
Vol. $27 \quad$ Feeding reconstituted and dried milk to calves
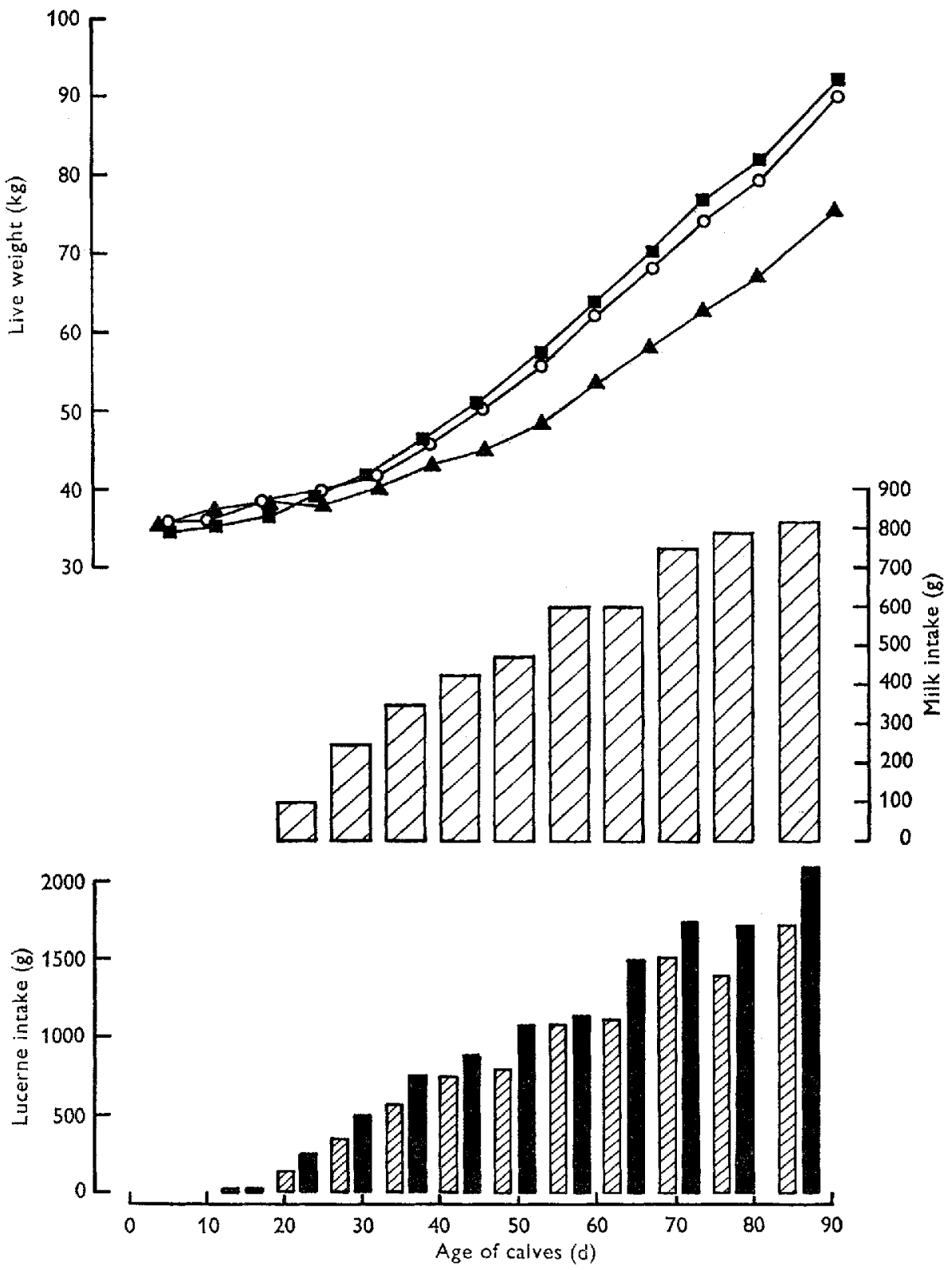

Fig. I. Mean live weights and milk and lucerne intakes of calves fed on dry (group DM) or reconstituted (groups LM and LMLA) milk. mean milk and lucerne intakes of group DM; $\boldsymbol{\square}$, mean lucerne intake of group LMLA. Milk intakes of calves in groups LM and LMLA and lucerne of calves in group LM were the same as the means for group DM. Mean live weights: $\mathbf{A}-\mathbf{A}$, group DM; $\mathrm{O}-\mathrm{O}$, group LM; $\mathbf{- 1}$, group LMLA. 


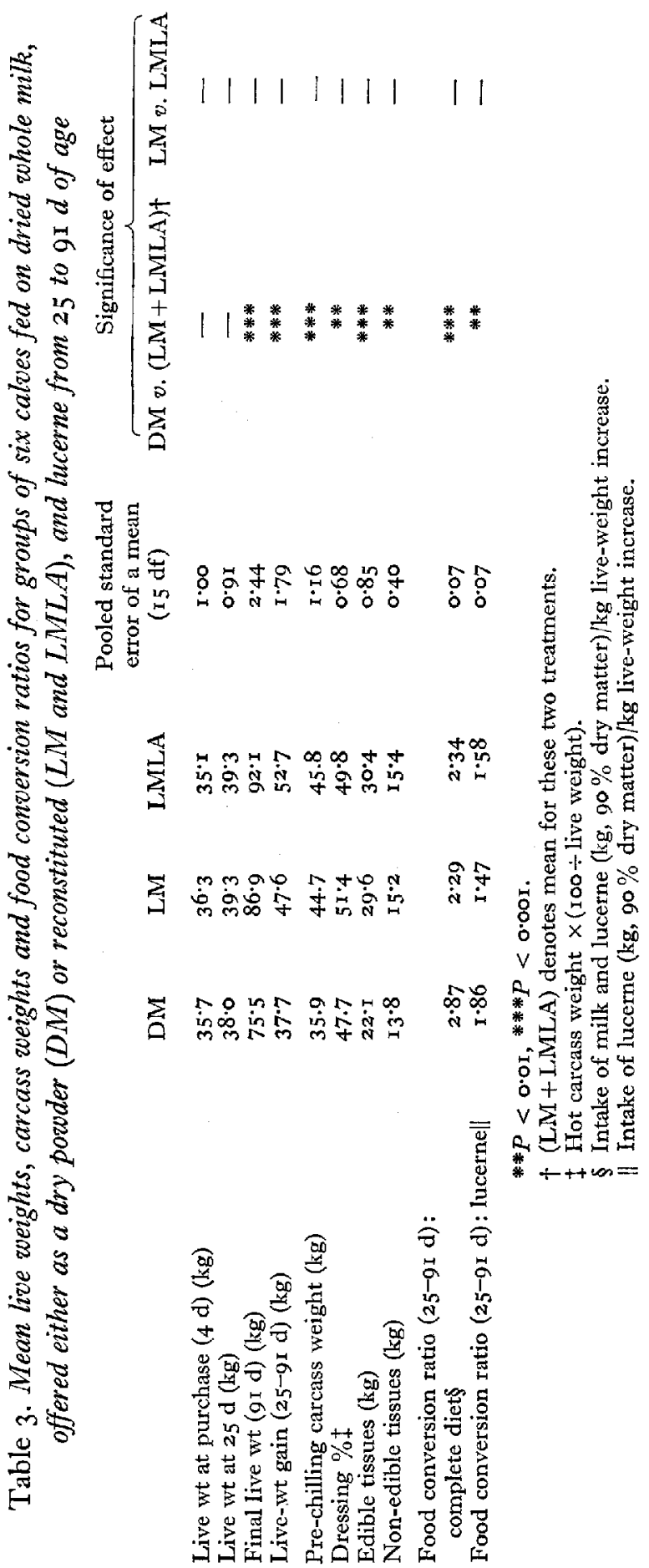


Vol. 27

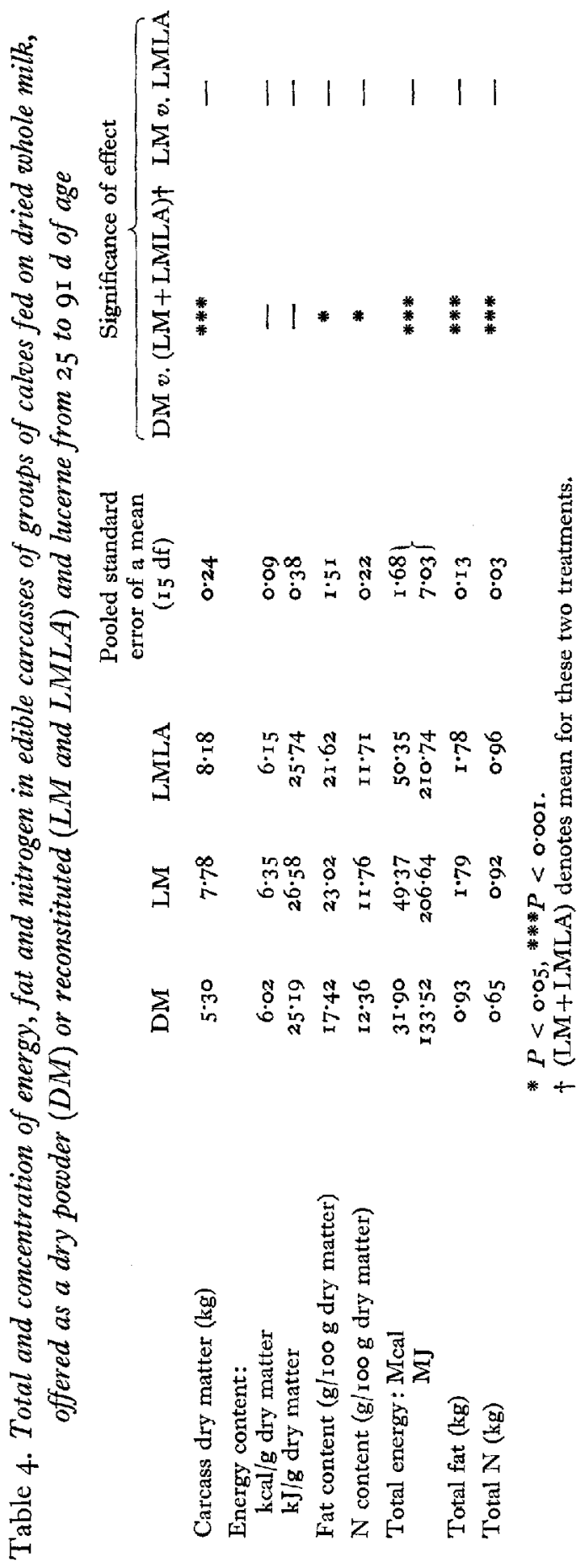


gained $40 \%$ more weight than those in group DM, but the non-significant difference between the live weights of the calves in groups LM and LMLA was largely due to differences in non-carcass weight. This is likely to be the result of differences in the weight of the gastro-intestinal tract and contents associated with the higher intake of lucerne.

Feeding with liquid milk was assumed to result in the reflex closure of the reticular groove (Hegland, Lambert, Jacobson \& Payne, 1957) so that the milk proteins, fat and lactose were digested by a monogastric type of digestion. Conversely, when the milk was given as a dry powder, the milk proteins, fat and lactose were digested initially within the rumino-reticulum.

The mean live-weight gains were $0.57,0.72$ and $0.79 \mathrm{~kg} / \mathrm{d}$ over the period $25^{-9} \mathrm{I} \mathrm{d}$ of age for the calves in groups DM, LM and LMLA respectively. For these live-weight gains the daily digestible $\mathrm{N}$ requirements for the three groups of calves would appear not to exceed $40 \mathrm{~g} / \mathrm{d}$ (Roy, r 9706 ) at any stage of the experiment, requirements considerably less than the amounts ingested by the calves. Thus, as in the experiments of Swanson et al. (1969), it is likely that the quantity of energy rather than of $N$ ingested was the limiting factor controlling live-weight gain, efficiency of food conversion and edible meat accretion. Black (I97 I) has concluded that the energy loss encountered when dietary fats are hydrolysed in the rumino-reticulum is $0.4 \%$, a loss which is insignificant in the present context. It therefore appears that the decisive factor in the inferior performance of the calves fed on dried-milk powder was the energy loss associated with the ruminal fermentation of lactose and milk protein.

Table 5 . Effciency $(\%)$ of the accretion of energy and nitrogen as edible tissues of unweaned and weaned calves given similar quantities of energy and nitrogen

\begin{tabular}{|c|c|c|c|c|c|c|c|}
\hline \multirow[b]{2}{*}{ Reference } & \multicolumn{3}{|c|}{$\begin{array}{l}\text { Calves given } \\
\text { liquid milk. } \\
\text { Group }\end{array}$} & \multicolumn{3}{|c|}{$\begin{array}{l}\text { Weaned calves. } \\
\text { Group }\end{array}$} & \multirow{2}{*}{$\begin{array}{l}\text { Pooled } \\
\text { SE of a } \\
\text { mean }\end{array}$} \\
\hline & LM & LMLA & $\mathrm{C}$ & $\mathrm{DM}$ & $A$ & B & \\
\hline & & & & Energ. & & & \\
\hline \multirow{3}{*}{$\begin{array}{l}\text { Present work } \\
\text { Ternouth \& Pryor (1970) }\end{array}$} & $7 \cdot 68$ & $7 \cdot 07$ & - & $4: 49$ & - & - & 0.28 \\
\hline & - & - & $7 \cdot 94$ & - & $4 \cdot 43$ & $5 \cdot 65$ & 0.30 \\
\hline & \multicolumn{7}{|c|}{ Nitrogen } \\
\hline Present work & $16 \cdot 92$ & $15 \cdot 28$ & - & II $\cdot 14$ & - & - & 0.91 \\
\hline Ternouth \& Pryor (1970) & - & - & 14.37 & - & 7.40 & $8 \cdot 30$ & 0.91 \\
\hline
\end{tabular}

Ternouth \& Pryor (1970) calculated the efficiency of energy and $\mathrm{N}$ accretion of edible tissue of calves between 19 and $87 \mathrm{~d}$ of age, the content at $19 \mathrm{~d}$ of age being estimated from values derived for six calves slaughtered at that age. These values are recorded by Pryor \& Johnson (1971). When these same values were used to calculate the gross energy and $\mathrm{N}$ contents of the calves at $25 \mathrm{~d}$ of age in the present experiment, the efficiencies of accretion of energy and $\mathrm{N}$ between 25 and $9 \mathrm{I} \mathrm{d}$ of age are as shown in Table 5. Ternouth \& Pryor (1970) included ligamentum nuchae in edible tissues obtained by dissection, whereas it was excluded during the boning-out procedure used in the present experiment. The effect of omitting it is considered to be of little 
quantitative importance. Comparison of the accretions between the two experiments showed that energy accretion was very similar for the two experiments though the efficiency of $\mathrm{N}$ accretion tended to be higher in the present experiment, both for the weaned and the liquid-fed calves. In both experiments feeding with liquid milk was associated with far higher accretions of energy and $\mathrm{N}$; in the present experiment the mean quantities of energy and $\mathrm{N}$ ingested were identical in both groups.

The milk intakes of all the calves were limited by the amount consumed by the calves in group DM. With higher intakes of liquid milk, as used for veal production, the maximal efficiency of $N$ accretion may be higher than the $16.9 \%$ recorded in the present experiment, since protein $\mathrm{N}$ was not limiting in the present experiment and with higher weight gains relatively less $\mathrm{N}$ would be utilized for maintenance.

The authors wish to thank Mr M. C. Knott and Mr A. R. Garrett for their technical assistance and the Australian Meat Research Committee and the Reserve Bank of Australia for providing some of the facilities used in this work.

\section{REFERENCES}

Aschaffenburg, R. \& Drewry, J. (1959). Int. Dairy Congr. xv. London 3, 1631.

Association of Official Agricultural Chemists (1965). Official Methods of Analysis roth ed. Washington, DC: Association of Official Agricultural Chemists.

Black, J. L. (1971). Br. F. Nutr. 25, 3 r.

Ferguson, K. A., Hemsley, J. A. \& Reis, P. J. (1967). Aust. F. Sci. 30, 215.

Hegland, R. B., Lambert, M. R., Jacobson, N. L. \& Payne, L. C. (I957). F. Dairy Sci. 40, I I07.

Ørskov, E. R. \& Benzie, D. (1969). Br. F. Nutr. 23, 4I 5.

Ørskov, E. R., Fraser, C. \& Corse, E. L. (1970). Br. $\%$. Nutr. 24, 803.

Pryor, W. J. \& Johnson, E. R. (1971). F. agric. Sci., Camb. 76, 459.

Reis, P. J. \& Tunks, D. A. (1969). Aust. F. agric. Res. 20, 775.

Roy, J. H. B. (I970a). F. Sci. Fd Agric. 21, 346.

Roy, J. H. B. ( $1970 b$ ). The Calf 3 rd ed. London: Iliffe.

Scott, T. W., Cook, L. J., Ferguson, K. A., McDonald, I. W., Buchanan, R. A. \& Hills, G. L. (I970). Int. Dairy Congr. xvir. Sydney 5, 509.

Swanson, E. W., Thigpen, J. E., Huskey, J. \& Hazlewood, B. P. (I969). Y. Dairy Sci. 52, 228.

Ternouth, J. H. \& Pryor, W. J. (1970). F. agric. Sci., Camb. 74, 559.

Zelter, S.-Z. \& Leroy, F. (1966-7). Z. Tierphysiol. Tierernähr. Futtermittelk. 22, 39. 